\title{
Development of an Efficient Method for Recovery of Puumala and Puumala-Related Viruses by Inoculation of Mongolian Gerbils
}

\author{
Nandadeva LOKUGAMAGE ${ }^{1}$, Hiroaki KARIWA ${ }^{1) *}$, Kumari LOKUGAMAGE $^{1)}$, Tomohiro HAGIYA ${ }^{1)}$, \\ Hironobu MIYAMOTO ${ }^{1)}$, Masahiro A. IWASA ${ }^{1)}$, Koichi ARAKI ${ }^{1)}$, Kumiko YOSHIMATSU ${ }^{2)}$, Jiro ARIKAWA ${ }^{2)}$, \\ Tetsuya MIZUTANI ${ }^{1)}$ and Ikuo TAKASHIMA ${ }^{1)}$ \\ ${ }^{1)}$ Graduate School of Veterinary Medicine and ${ }^{2}$ School of Medicine, Hokkaido University, Sapporo 060-0818, Japan
}

(Received 23 April 2003/Accepted 22 July 2003)

\begin{abstract}
Puumala (PUU) virus and PUU-related viruses are difficult to isolate in cell culture. To determine whether animal inoculation would be a better alternative for virus recovery, the Sotkamo strain of PUU virus was inoculated into several animal species. Newborn Mongolian gerbils (MGs), mice, and rats were infected with the Sotkamo strain by intracerebral (ic), intraperitoneal (ip), and subcutaneous (sc) inoculation. Antibodies to PUU appeared in MGs at 30 days post-infection (dpi), and in mice and rats at 15 dpi. Interestingly, virus appeared at $7 \mathrm{dpi}$ in lung and brain of MGs inoculated via ic and ip routes. Virus was detected in all tested tissues of MGs at 15 $\mathrm{dpi}$, with a peak level of $1.36 \times 10^{5}$ focus forming units (FFU)/g in brain tissue. The virus titer declined with the onset of the antibody response and became undetectable by $75 \mathrm{dpi}$, when the antibody titer reached the maximum level. The appearance of the virus in mice and rats was delayed as compared to MGs, and the virus titer was apparently lower, at approximately 4 to $8 \times 10^{3} \mathrm{FFU} / \mathrm{g}$, at $15 \mathrm{dpi}$. In addition, lung homogenates of antibody-positive Clethrionomys (C.) rufocanus (captured in Tobetsu, Hokkaido, Japan) were inoculated into MGs by the ic route. PUU-related viral RNA was detected at 16 dpi in the brains of MG inoculated with the lung homogenate, and antibodies were detected at $45 \mathrm{dpi}$. These findings indicate that newborn MG inoculation is an efficient method to recover PUU and PUU-related viruses.

KEY WORDS: Clethrionomys rufocanus, Hantavirus, Mongolian gerbil, Puumala virus, Rodent.
\end{abstract}

J. Vet. Med. Sci. 65(11): 1189-1194, 2003

Hantaviruses cause hemorrhagic fever with renal syndrome (HFRS) in Europe and Asia, and hantavirus pulmonary syndrome (HPS) in the Americas [6, 16, 22, 25, 26]. It is believed that there is a close relationship between hantaviruses and the specific rodent species in which they establish inapparent and persistant infections [23]. Hantaan (HTN), Seoul (SEO), and Dobrava (DOB) viruses cause a severe form of HFRS and are carried by Murinae rodents [1, 2, 17, 18]. Arvicolinae rodents are considered to be the reservoir hosts of Puumala (PUU), Tula (TUL), Topografov (TOP) and Khabarovsk (KBR) viruses [15, 23]. Sigmodontine rodents are the most common rodent species in the Americas and are the reservoir animals for Sin Nombre (SN), Andes (AND), Bayou (BAY), Black Creek Canal (BCC), and New York (NY) viruses [7, 10, 11,19, 20, 24, 27]. Primary hosts shed viruses into urine, saliva, and feces, and virus transmission to humans occurs via aerosolized rodent excreta $[21,28]$ or via contaminated saliva in animal bites [8].

Members of the genus Hantavirus of the family Bunyaviridae are negative strand RNA viruses with tripartite genomes. The segments have been designated, based on their sizes, as large (L), medium (M), and small (S). The L segment encodes a viral RNA polymerase, while $M$ and $S$ encode two surface glycoproteins G1 and G2, and a nucleo-

* Correspondence to: Kariwa, H., Laboratory of Public Health, Graduate School of Veterinary Medicine, Hokkaido University, Sapporo, Hokkaido 060-0818, Japan. capsid protein (NP), respectively [9].

PUU virus is the causative agent of a mild form of hemorrhagic fever with renal syndrome, nephropathia epidemica [23]. PUU virus was first discovered in bank voles (C. glareolus) in Puumala, Finland in 1980 [4]. The Sotkamo strain is the prototype strain of PUU virus and was discovered in C. glareolus in Sotkamo, Finland (5). Although C. glareolus is considered the primary host species for PUU virus, the agent has also been isolated from C. rufocanus [29]. Recent studies in Hokkaido, Japan revealed the presence of PUUlike viruses in $C$. rufocanus [12, 13]. Although human infection has not been reported in Japan, antibodies in human sera have been found in the general public and in high-risk groups that have close contacts with rodents [3]. Isolation of the virus from $C$. rufocanus by direct inoculation to cultured cells has not been successful, and isolation of the PUU virus poses significant difficulties.

In the present study, we attempted to find a suitable animal species for isolation of PUU virus as an alternative method to cell culture inoculation. New born Mongolian gerbils (MGs), mice, and rats were inoculated with the Sotkamo strain of PUU virus. In the early stage of infection, MGs had high virus titers in several tested organs and no antibody response was observed. Mice and rats had earlier onset of antibody responses and lower virus titers than MGs. These data suggest that the MG is an ideal animal species for PUU virus isolation from wild rodent samples. 


\section{MATERIALS AND METHODS}

Cells and virus: The Sotkamo strain of PUU virus which has 14 passage history in Vero E6 cells, was propagated in Vero E6 cells maintained in Eagle's minimum essential medium (MEM: Nissui, Tokyo, Japan) supplemented with $5 \%$ fetal calf serum and L-glutamine. After incubation for seven days, the supernatant from the cell monolayer was collected and stored at $-80^{\circ} \mathrm{C}$ for use as the virus stock.

Animals: Pregnant MGs (Mon/Jms/Gbs), ICR mice, and Wistar rats were purchased from SLC, Inc., Hamamatsu, Japan. Newborn (within $24 \mathrm{hr}$ after birth) MGs, mice, and rats were inoculated intracerebrally (ic), intraperitoneally (ip) and subcutaneously (sc) with the Sotkamo strain of the PUU virus at 496, 1240, and $1240 \mathrm{FFU} /$ animal, respectively. As a negative control, newborn MGs were inoculated with MEM via ic, ip, and sc routes. Animals were observed everyday, and body weight was recorded periodically. At 15, 30, and 75 days post-inoculation (dpi), two or three animals were sacrificed for collection of serum, brain, lung, spleen, kidney, and liver samples.

In addition, newborn MGs were inoculated intracerebrally with lung and kidney homogenates from one wild $C$. rufocanus captured in Tobetsu, Japan, which was seropositive and had virus genome in lungs. Animals were sacrificed at 16 and $45 \mathrm{dpi}$ and sera and organs were collected.

Dams were allowed to feed newborns, and water and food pellets were provided ad libitum. All animal experiments were carried out under biosafety level 3 containment conditions, according to the guideline of the School of Veterinary Medicine, Hokkaido University.

Indirect immunofluorescent antibody test (IFA): The sera were tested for antibodies to PUU virus by an indirect immunofluorescent antibody (IFA) test. Antigen slides were prepared by spotting Vero E6 cells, infected with the Sotkamo strain of the PUU virus, onto 24 -well slides. After incubation for $4 \mathrm{hr}$ at $37^{\circ} \mathrm{C}$, the cells were fixed with cold acetone and air-dried. Sera from MGs were diluted in phosphate-buffered saline (PBS), spotted on to antigen slides, and incubated for $1 \mathrm{hr}$ at $37^{\circ} \mathrm{C}$. After three washes with PBS, fluorescein isothiocyanate (FITC)-conjugated protein G (Zymed Laboratories, Inc, U.S.A.) was applied. After incubation at $37^{\circ} \mathrm{C}$ for $1 \mathrm{hr}$, the slides were washed and observed under a fluorescence microscope. Scattered granular florescence in the cytoplasm of infected Vero E6 cells was regarded as a positive reaction.

Titration of virus: The Sotkamo strain of the PUU virus was used to inoculate newborn MGs, mice, and rats. To determine virus titers in the organs of infected animals, $10 \%$ tissue homogenates were serially diluted and inoculated onto confluent Vero E6 cells in 8-well chamber slides. After incubation at $37^{\circ} \mathrm{C}$ for $1 \mathrm{hr}$ in a $\mathrm{CO}_{2}$ incubator, the inoculum was discarded and the slides were covered with $1.5 \%$ carboxymethyl cellulose (CMC) in MEM. The slides were kept at $37^{\circ} \mathrm{C}$ for 5 days in a $\mathrm{CO}_{2}$ incubator. The viral foci were visualized by IFA to determine the virus titers.

Reverse transcription- polymerase chain reaction (RT-
$P C R)$ : Total RNA was extracted from brain and lung tissues of MGs inoculated with lung materials of seropositive $C$. rufocanus using Isogen (Nippon Gene Co., Ltd., Osaka, Japan) according to the manufacturer's instructions.

Reverse transcription was carried out at $42^{\circ} \mathrm{C}$ for $50 \mathrm{~min}$ with superscript II and Random primers (Gibco-BRL, Rockville, MD). Part of the S segment was amplified with AmpliTaq DNA polymerase (Applied Biosystems, Foster City, CA) and PUU virus-specific primers (Tobetsu 1: 5'-CTATGTTGCAGGAATGGCAG-3' and Puu-full-S-new: 5'TTCTGCAGTAGTAGTAGACTCCTTGAA-3') for 35 PCR cycles of denaturation at $94^{\circ} \mathrm{C}$ for $1 \mathrm{~min}$, annealing at $55^{\circ} \mathrm{C}$ for $1 \mathrm{~min}$, and extension at $72^{\circ} \mathrm{C}$ for $2 \mathrm{~min}$. Two microliters of each PCR product mixture were then subjected to a nested-PCR with the same PCR protocol, except for the use of inner primers (PUU $1129 \mathrm{Fw}$ : 5'-TCAT CTTTCTACCAATCATAT-3' and PUU 1801 Rv: 5'ATCAGCATGTTGAGGTAGTA-3').

\section{RESULTS}

IFA antibody response in animals inoculated with PUU virus: Antibodies of MGs, mice, and rats inoculated with the Sotkamo strain of the PUU virus were detected in sera by IFA (Fig. 1). In the early stage of infection (7 dpi), antibody responses were undetectable in MGs, mice, and rats, regardless of inoculation route. Antibody responses were detectable from $15 \mathrm{dpi}$ in mice and rats, with titers ranging from $1: 16$ to $1: 256$. In contrast, MGs showed no antibody response at this time point. By $30 \mathrm{dpi}$, MGs had developed antibody responses, with an average titer of 1:512. Almost all animals had high antibody responses, with IFA titers of 1:2048 at $75 \mathrm{dpi}$, when observations were terminated. These data suggest that MGs had a delayed antibody response to PUU virus as compared to the responses in mice and rats.

$P U U$ virus replication in infected animals:

Mongolian gerbils: We measured virus titers in organs of infected MGs by inoculation of cultured cells and detection of foci by IFA. Virus titers in MGs are shown in Table 1 and Fig. 1A, along with antibody titers. Virus was present in significant amounts at $7 \mathrm{dpi}$ in most of the tested tissues. By $15 \mathrm{dpi}$, virus was present in all tissues except liver, with the highest viral titer $\left(1.36 \times 10^{5}\right)$ detected in lung. At $30 \mathrm{dpi}$, virus was detectable only in brain tissues. It is clear that there was a good correlation between the absence of IFA antibody response in sera and the presence of virus in several organs of infected MGs, regardless of the route of inoculation. Further, virus titers in tissues declined with the onset of the antibody response. Moreover, virus became undetectable at $75 \mathrm{dpi}$, when IFA antibody responses peaked. No obvious symptoms were observed in the inoculated MGs during the observation period.

Mice: PUU virus can replicate in mice, but less efficiently than in MGs. Although infected mice had no IFA antibodies in sera at $7 \mathrm{dpi}$, we were unable to detect virus from brain, lung, kidney, spleen, and liver at that time (Table 2 and Fig. 

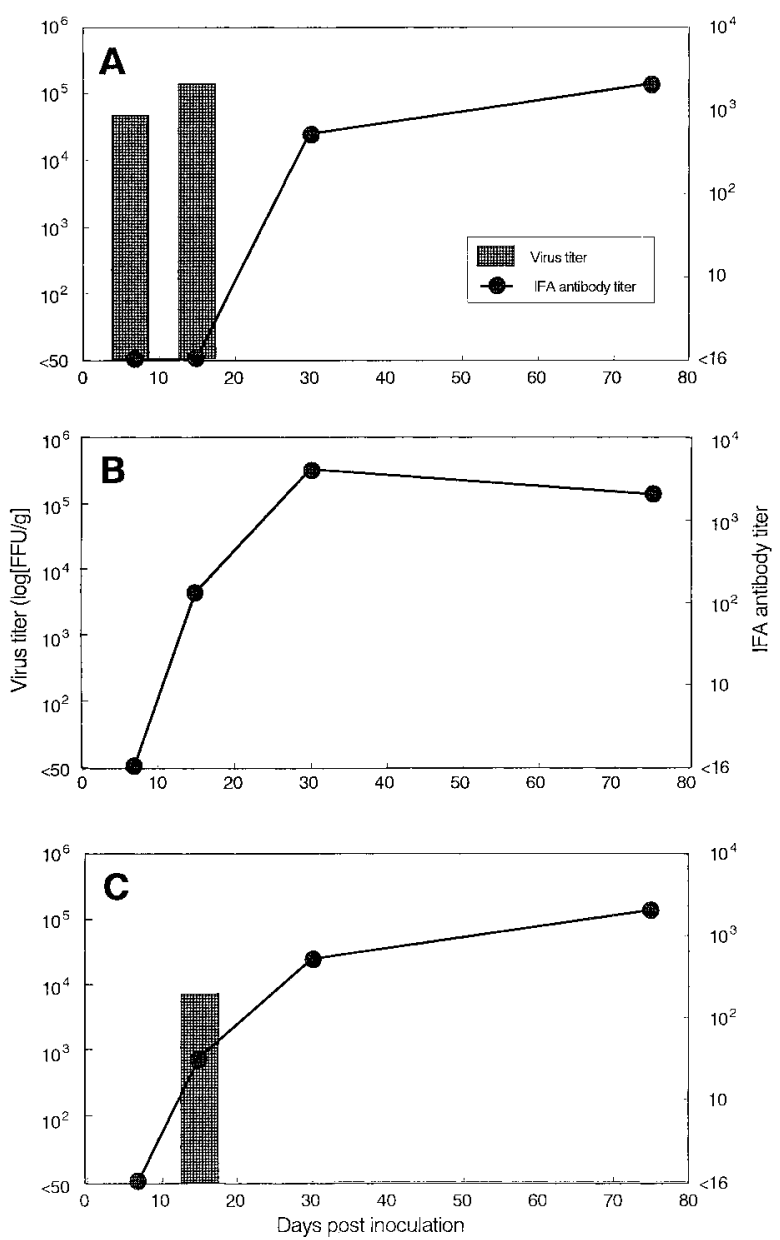

Fig. 1. Antibody response and virus titer in lungs of MGs (A), mice (B), and rats (C) inoculated with Sotkamo strain of PUU virus by the ic route. The Sotkamo strain was inoculated ic at 496 FFU/animal. The inoculated animals were maintained in an animal room with biosafety level 3 containments and sacrificed at $7,15,30$, and $75 \mathrm{dpi}$. Anti-hantavirus antibody was titrated by IFA and virus load in the lung was measured by inoculation of the brain homogenate to Vero E6 monolayers followed by detection of foci by IFA. Columns indicate virus titer and closed circles represent IFA antibody titer.

1B). Virus was detected at 15 dpi only in the brain tissues of ic-inoculated mice. After $30 \mathrm{dpi}$, all tested tissues were again negative for virus. No symptoms were observed.

Rats: Rats demonstrated a pattern of infection and response similar to that of mice (Table 2 and Fig. 1C). Virus was not detected at $7 \mathrm{dpi}$, in spite of the absence of an antibody response at that time. At $15 \mathrm{dpi}$, virus was present only in brain and lung tissues, and subsequently became undetectable from $30 \mathrm{dpi}$ onwards. The virus was not detected in kidney, spleen, and liver in any time. No symptoms were observed.

Body weight changes in virus inoculated and control MGs: The body weight of infected MGs was measured periodically during the observation period (Fig. 2). Although no obvious symptoms were observed, growth from 2 to $7 \mathrm{dpi}$ $(\mathrm{p}<0.01)$ and $10 \mathrm{dpi}(\mathrm{p}<0.05)$ was significantly delayed in MGs inoculated with PUU virus via the ic route, as compared to control MGs inoculated with MEM. Although there were no significant differences in body weight between infected and control groups at 15 and $20 \mathrm{dpi}$, the infected gerbils seemed to grow slower than the control animals.

IFA antibody response and viral genome detection by $R T$ PCR in MGs inoculated with lung homogenates of wild $C$. rufocanus: Lung homogenates $(0.1 \%, 1 \%$, and $10 \%)$ from seropositive and viral-genome positive $C$. rufocanus were inoculated into newborn MG by the ic route. MGs were sacrificed at 16 and $45 \mathrm{dpi}$ for collection of organs and sera. At 16 dpi, when IFA antibody was undetectable, viral genome was detected in brains of MGs inoculated with $10 \%$ lung homogenates (Fig. 3, Table 3). When IFA antibodies became detectable at $45 \mathrm{dpi}$, in MGs inoculated with $1 \%$ and $10 \%$ lung homogenates, PCR results were negative.

\section{DISCUSSION}

Although no HFRS cases have been reported recently in Japan, anti-hantavirus antibodies have been detected among patients with hepatitis of unknown etiology [14] and in high-risk group. In addition, infected Rattus norvegicus and C. rufocanus have been found in Hokkaido [12, 13]. Further, surveys in Sakhaline, Russia, also revealed the presence of a PUU-like virus in C. rufocanus (Unpublished data). Although PUU-like virus genomes have been amplified and sequenced from $C$. rufocanus, virus isolation in cell cultures has failed, despite extensive attempts. In Europe, C. glareolus colonies are used to isolate PUU virus. However, in Japan no C. glareolus colonies are available, nor is it possible to maintain stable colonies of $C$. rufocanus in laboratory, due to difficulties in providing the conditions required by this species. Consequently, further studies of PUU-like virus in $C$. rufocanus have been severely hampered. To see whether animal inoculation could be a better means for virus isolation, we compared PUU virus infection in MGs, mice, and rats.

MGs developed detectable virus in their lung tissues at 7 dpi, while the other two species remained negative for the presence of virus in all tested tissues. By $15 \mathrm{dpi}$, mice and rats had detectable levels of virus in some tissues, but MGs had higher viral loads, with viral titers about 18-fold higher in lung tissue as compared to mice and rats. In addition, virus was detectable in MGs up to $30 \mathrm{dpi}$, while it was not in the other two species. These data indicate that PUU virus replicates well in the brain and lungs of MGs during the early stage of infection, before the development of antibody responses. The concomitant occurrence of a delayed antibody response and high virus titers in organs during the early stage of infection is an important factor for isolation of virus from organs of infected MGs.

In addition, we found that PUU virus replicated well in the brains and lungs of infected MGs, implying that virus 
Table 1. Virus titer in Mongolian gerbils inoculated with Sotkamo strain

\begin{tabular}{|c|c|c|c|c|c|c|c|}
\hline \multirow[t]{2}{*}{$\mathrm{Dpi}^{\mathrm{a})}$} & \multirow{2}{*}{$\begin{array}{l}\text { Route of } \\
\text { inoculation }\end{array}$} & \multirow[t]{2}{*}{ IFA titer } & \multicolumn{3}{|c|}{ Virus titer } & \multicolumn{2}{|c|}{ FFU/tissue) } \\
\hline & & & Brain & Lung & Kidney & Spleen & Liver \\
\hline \multirow[t]{4}{*}{7} & ic- $1^{\text {b) }}$ & $<16$ & $<50$ & $4.8 \times 10^{4}$ & $<50$ & $4 \times 10^{2}$ & $<50$ \\
\hline & $\mathrm{sc}-1^{\mathrm{c})}$ & $<16$ & $<50$ & $2.1 \times 10^{4}$ & $8 \times 10^{2}$ & $8 \times 10^{2}$ & $8 \times 10^{2}$ \\
\hline & sc-2 & $<16$ & $<50$ & $1.36 \times 10^{4}$ & $<50$ & $8 \times 10^{2}$ & $4 \times 10^{2}$ \\
\hline & ip- $1^{\text {d) }}$ & $<16$ & $4 \times 10^{2}$ & $<50$ & $<50$ & $<50$ & $<50$ \\
\hline \multirow[t]{4}{*}{15} & ic-1 & $<16$ & $4.8 \times 10^{4}$ & $1.35 \times 10^{5}$ & $<50$ & $6.4 \times 10^{3}$ & $<50$ \\
\hline & sc-1 & $<16$ & $1.36 \times 10^{5}$ & $5.2 \times 10^{4}$ & $1.6 \times 10^{3}$ & $8.2 \times 10^{2}$ & $<50$ \\
\hline & sc-2 & $<16$ & $2.4 \times 10^{3}$ & $1.6 \times 10^{4}$ & $<50$ & $8.2 \times 10^{2}$ & $<50$ \\
\hline & ip-1 & $<16$ & $6.2 \times 10^{2}$ & $6.8 \times 10^{4}$ & $4 \times 10^{2}$ & $<50$ & $<50$ \\
\hline \multirow[t]{2}{*}{30} & ic-1 & 512 & $3.2 \times 10^{3}$ & $<50$ & $<50$ & $<50$ & $<50$ \\
\hline & sc-1 & 512 & $2.8 \times 10^{3}$ & $<50$ & $<50$ & $<50$ & $<50$ \\
\hline \multirow[t]{2}{*}{75} & ic-1 & 2048 & $<50$ & $<50$ & $<50$ & $<50$ & $<50$ \\
\hline & sc-1 & 2048 & $<50$ & $<50$ & $<50$ & $<50$ & $<50$ \\
\hline
\end{tabular}

a) Days post inoculation. b) Intracraneal. c) Subcutaneous. d) Intraperitoneal.

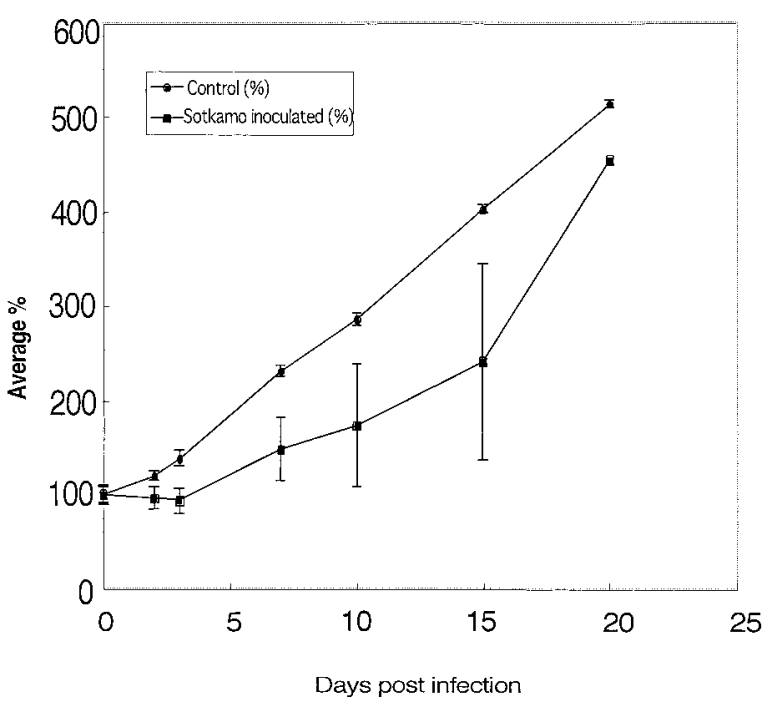

Fig. 2. Growth in MGs inoculated with the Sotkamo strain of the PUU virus by the ic route. The infected animals were fed $a d$ libitum in an animal room with biological safety level 3 containments. The body weight of the animals was measured consecutively. closed squares represent weights of infected MGs and closed circles represent weights of control MGs.

could be most easily recovered from those organs. Furthermore, the delay in growth of MGs inoculated by the ic route correlated with the replication of virus in the brain.

Based on these data, we suggest that MGs are the suitable animal to isolate PUU-like viruses in $C$. rufocanus.

To determine whether MGs could be used to recover virus from naturally-infected $C$. rufocanus, we inoculated lung homogenates of wild-caught, seropositive $C$. rufocanus into newborn MGs. During the early stage of infection (16 dpi), the viral genome was detected in brains of inoculated MGs. In addition, antibody responses were delayed, being undetectable at $16 \mathrm{dpi}$ but appearing by $45 \mathrm{dpi}$. These findings are similar to those observed in MGs inoculated with laboratory stocks of the Sotkamo strain. C. rufocanus is widely distributed in the Palaearctic region. We have also found PUU-like viral RNA sequences in animals of this species captured in far eastern Russia (unpublished data). Therefore, the MG inoculation method may be applicable for the isolation of PUU-related viruses from different geographical regions.

In conclusion, inoculation of samples into MGs through ic or sc routes could be an efficient method for isolation of PUU and PUU-like viruses from wild rodent samples. Further attempts to isolate PUU-like viruses from C. rufocanus by this method are currently underway.

ACKNOWLEDGMENTS. This work was supported partly by Grants-in-Aid for Scientific Research from the Ministry of Education, Science, Culture, and Sport, of Japan, and by Health Science Grants for Research on Emerging and Reemerging Infectious Diseases from the Ministry of Health, Labor, and Welfare, of Japan.

\section{REFERENCES}

1. Antoniadis, A., Stylianakis, A., Papa, A., Alexiou-Daniel, S., Lampropoulos, A., Nichol, S. T., Peters, C. J. and Spiropoulou, C. F. 1996. Direct genetic detection of Dobrava virus in Greek and Albanian patients with hemorrhagic fever with renal syndrome. J. Infect. Dis. 174: 407-410.

2. Avsic-Zupanc, T., Petrovec, M., Furlan, P., Kaps, R., Elgh, F. and Lundkvist, A. 1999. Hemorrhagic fever with renal syndrome in the Dolenjska region of Slovenia - a 10- year survey. Clin. Infect. Dis. 28: 860-865.

3. Arikawa, J., Yoshimatsu, K. and Kariwa, H. 2001. Epidemiology and epizootiology of hantavirus infection in Japan. Jpn. J. Infect. Dis. 54: 95-102.

4. Brummer-Korvenkontio, M., Vaheri, A., Hovi, T., Von Bonsdorff, C.H., Vuorimies, J., Manni, T., Penttinen, K., OkerBlom, N. and Lahdevirta, J. 1980. Nephropathia epidemica: detection of antigen in bank voles and serologic diagnosis of human infection. J. Infect. Dis. 141: 131-134.

5. Brummer-Korvenkontio, M., Henttonen, H. and Vaheri, A. 1982. Hemorrhagic fever with renal syndrome in Finland: ecol- 
Table 2. Virus titer in mice and rats inoculated with Sotkamo strain

\begin{tabular}{|c|c|c|c|c|c|}
\hline \multirow[t]{2}{*}{ Animal } & \multirow[t]{2}{*}{$\mathrm{Dpi}^{\mathrm{a})}$} & \multirow{2}{*}{$\begin{array}{c}\text { Route of } \\
\text { inoculation }\end{array}$} & \multirow[t]{2}{*}{ IFA titer } & \multirow{2}{*}{$\frac{\text { Virus titer }}{\text { Brain }}$} & \multirow{2}{*}{$\frac{\text { (FFU/tissue) }}{\text { Lung }}$} \\
\hline & & & & & \\
\hline \multirow[t]{12}{*}{ Mice } & 7 & ic- $1^{\text {b) }}$ & $<16$ & $<50$ & $<50$ \\
\hline & & ic-2 & $<16$ & $<50$ & $<50$ \\
\hline & & ic-3 & $<16$ & $<50$ & $<50$ \\
\hline & & $\mathrm{sc}-1^{\mathrm{c})}$ & $<16$ & $<50$ & $<50$ \\
\hline & & sc-2 & $<16$ & $<50$ & $<50$ \\
\hline & & sc-3 & $<16$ & $<50$ & $<50$ \\
\hline & 15 & ic-1 & 128 & $<50$ & $<50$ \\
\hline & & ic-2 & 16 & $4 \times 10^{3}$ & $<50$ \\
\hline & & ic-3 & 128 & $8 \times 10^{3}$ & $<50$ \\
\hline & & sc-1 & 256 & $<50$ & $<50$ \\
\hline & & sc-2 & 128 & $<50$ & $<50$ \\
\hline & & sc- -3 & 32 & $<50$ & $<50$ \\
\hline \multirow[t]{17}{*}{ Rat } & 7 & ic- $1^{\text {b) }}$ & $<16$ & $<50$ & $<50$ \\
\hline & & ic- 2 & $<16$ & $<50$ & $<50$ \\
\hline & & ic-3 & $<16$ & $<50$ & $<50$ \\
\hline & & $\mathrm{sc}-1^{\mathrm{c})}$ & $<16$ & $<50$ & $<50$ \\
\hline & & sc-2 & $<16$ & $<50$ & $<50$ \\
\hline & & sc-3 & $<16$ & $<50$ & $<50$ \\
\hline & & $i p-1^{d)}$ & $<16$ & $<50$ & $<50$ \\
\hline & & ip-2 & $<16$ & $<50$ & $<50$ \\
\hline & & ip-3 & $<16$ & $<50$ & $<50$ \\
\hline & 15 & ic- 1 & $<16$ & $7 \times 10^{3}$ & $1.2 \times 10^{3}$ \\
\hline & & ic-2 & 32 & $4.5 \times 10^{3}$ & $7.2 \times 10^{3}$ \\
\hline & & sc-1 & 128 & $<50$ & $1.6 \times 10^{3}$ \\
\hline & & $\mathrm{sc}-2$ & 64 & $<50$ & $2.4 \times 10^{3}$ \\
\hline & & sc-3 & 128 & $<50$ & $2.4 \times 10^{3}$ \\
\hline & & ip-1 & 32 & $<50$ & $<50$ \\
\hline & & ip-2 & 16 & $<50$ & $8 \times 10^{3}$ \\
\hline & & ip-3 & $<16$ & $<50$ & $4 \times 10^{2}$ \\
\hline
\end{tabular}

a) Days post inoculation. b) Intracraneal inoculation. c) Subcutaneous inoculation. d) Intraperitoneal inoculation.

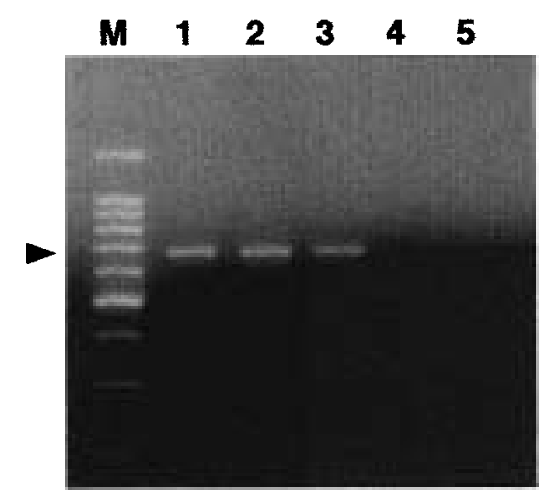

Fig. 3. Detection of PUU-related viral RNA in MGs inoculated with lung homogenates from seropositive $C$. rufocanus. New borne MGs were inoculated with lung homogenates from seropositive $C$. rufocanus and maintined in an animal room with biosafety level 3 containments. The inoculated MGs were sacrificed on 16 dpi and RNA from the brain was subjected to RT-Nested PCR. M: Molecular marker. Lanes 1 to 3: Brains of MGs inoculated with $10 \%$ C. rufocanus lung homogenates. Lanes 4 and 5: Brains of MGs inoculated with the $1 \%$ and $0.1 \%$ lung homogenates, respectively. Each lane number was matched with MG number in Table 3. ogy and virology of nephropathia epidemmica. Scand. J. Infect. Dis. (Suppl.) 36: 88-91.

6. CDC update: hantavirus pulmonary syndrome - United States, 1993. MMWR Morb. Mortal. Wkly. Rep. 42: 421-424.

7. Childs, J. E., Ksiazek, T. G., Spiropoulou, C. F., Krebs J. W., Morzunov, S., Maupin, G. O., Gage, K. L., Rollin, P., Sarisky, J., Enscore, R., Peters, C. J. and Nichol, S. T. 1994. Serologic and genetic identification of peromyscus maniculatus as the primary rodent reservoir for a new hantavirus in South Western United States. J. Infect. Dis. 168: 1271-1280.

8. Douron, E., Moriniere, B., Matheron, S., Girard, P. M., Gonzalez, J. P., Hirsch, F. and McCrromick, J. B. 1984. HFRS after a wild rodent bite in the Haute-savoie- and risk of exposure to Hantaan-like virus in a Paris laboratory. Lancet 1: 676-677.

9. Elliot, R. M. 1990. Molecular biology of the Bunyaviridae. $J$. Gen. Virol. 71: 501-522.

10. Hjelle, B., Goade, D., Torrez-Martinez, N., Lang-Williams, M., Kim, J., Harris, S. R. L. and Rawlings, J. A. 1996. Hantavirus pulmonary syndrome renal insufficiency, and myositis associated with infection by Bayon hantavirus. Clin. Infect. Dis. 23: 495-500.

11. Khan, A. S., Gaviria, M., Rollin, P. E., Hlady, W. G., Ksizek, T. G., Armstrong, L. R., Greenman, R., Ravkov, E., Kolber, M., Anapol, H., Stakianaki, E. D., Nichol, S. T., Peters, C. J. and Kabbaz, R. F. 1996. Hantavirus pulmonary syndrome in Florida- association with the newly identified Black Creek 
Table 3. Antibody response and virus detection in Mongolian gerbils inoculated with lung homogenates of sero positive $C$. rufocanus captured in Tobetsu town

\begin{tabular}{|c|c|c|c|c|c|}
\hline \multirow{2}{*}{$\begin{array}{l}\text { Mongolian gerbil } \\
\text { number }\end{array}$} & \multirow{2}{*}{$\begin{array}{l}\text { Concentration of } \\
\text { Inoculum (\%) }\end{array}$} & \multirow{2}{*}{$\begin{array}{l}\text { Days post } \\
\text { inoculation }\end{array}$} & \multirow{2}{*}{$\begin{array}{c}\text { IFA } \\
\text { TITER }\end{array}$} & \multicolumn{2}{|c|}{ PCR } \\
\hline & & & & Lung & Brain \\
\hline 1 & 10 & 16 & $<16$ & $(-)$ & $(+)$ \\
\hline 2 & 10 & 16 & $<16$ & $(-)$ & $(+)$ \\
\hline 3 & 10 & 16 & $<16$ & $(-)$ & $(+)$ \\
\hline 4 & 1 & 16 & $<16$ & $(-)$ & $(+)$ \\
\hline 5 & 0.1 & 16 & $<16$ & $(-)$ & $(+)$ \\
\hline 6 & 10 & 45 & 128 & $(-)$ & $(-)$ \\
\hline 7 & 10 & 45 & 128 & $(-)$ & $(-)$ \\
\hline 8 & 1 & 45 & 128 & $(-)$ & $(-)$ \\
\hline 9 & 0.1 & 45 & $<16$ & $(-)$ & $(-)$ \\
\hline
\end{tabular}

Canal virus. Am. J. Med. 100: 46-48.

12. Kariwa, H., Yoshizumi, S., Arikawa, J., Yoshimatsu, K., Takahashi, K., Takashima, I. and Hashimoto, N. 1995. Evidence for the existence of Puumala-related virus among Clethrionomys rufocanus in Hokkaido, Japan. Am. J. Trop. Med. Hyg. 53: 222-227.

13. Kariwa, H., Yoshimatsu, K., Sawabe, J., Yokota, E., Arikawa, J. and Takashima, I. 1999. Genetic diversities of hantaviruses among rodents in Hokkaido, Japan and Far East Russia. Virus Res. 59: 219-228.

14. Kariwa, H., Yoshimatsu, K., Araki, K., Murphy, M. E., Ebihara, H., Ogino, M., Mizutani, T., Arikawa, J., Chayama, K., Kumada, H. and Takashima, I. 2000. Detection of hantavirus antibodies among patients with hepatitis of unknown etiology in Japan. Microbiol. Immunol. 44: 357-362.

15. Lundkvist, A. and Plyusnin, A. 2002. Molecular Epidemiology of Hantavirus infection. Chapter 15. In: The Molecular Epidemiology of Human Viruses.

16. Lee, H. and Vander Groen, G. 1989. Hemorrhagic fever with renal syndrome. Prog. Med. Virol. 36: 62-102.

17. Lee, H. W. 1996. Epidemilogy and pathogenesis of hemorrhagic fever with renal syndrome. pp. 253-267. In: Elliott, R. M. ed.), The Bunyaviridae. Plenum Press, New York.

18. Lundkvist, A., Apekina, N., Myasnikov, Y., Vapalahti, O., Vaheri, A. and Plyusnin, A. 1997. Dobrava hantavirus outbreak in Russia. Lancet. 350: 781-782.

19. Lopez, N., Padula, P., Rossic, C., Miguel, S., Edestein, A., Ramirez, E. and Franz-Fernandez, M. T. 1997. Genetic characterization and phylogeny of Andes virus and variant from Argentina and Chile. Virus Res. 42: 143-152.

20. Monroe, M. C., Morzunov, S. P., Johnson, A. M., Bowen, M. D., Artsob, H., Yates, T., Peters, C. J., Rollin, P. E., Ksiazek, T. G. and Nichol, S. T. 1999. Genetic diversity and distribution of Peromyscus with other hantaviruses in North America and comparison with other hantaviruses. Emerg. Infect. Dis. 5: 7586.

21. Meyer, B. J. and Schmaljohn, C. S. 2000. Persistent hantavirus infections: Characteristics and mechanisms. Trends. Microbiol. 8: 61-67.

22. Nichol, S., Spiropoulou, C., Morzunof, S., Rollin, P., Ksiazek, T., Feldmann, H., Sanchez, A., Childs, J., Zaki , S. and Peters, C. J. 1993. Genetic identification of a hantavirus associated with an outbreak of acute respiratory illness. Science 262: 914 917.

23. Plyusnin, A., Vapalahti, O. and Vaheri, A. 1996. Hantaviruses: genome structure, expression and evolution. J. Gen. Virol. 77: 2677-2687.

24. Peters, C. J., Simpson, G. L. and Levy, H. 1999. Spectrum of hantavirus infection: hemorrhagic fever with renal syndrome and hantavirus pulmonary syndrome. Annu. Rev. Med. 50: 531-545.

25. Rai, S., Shibata, H., Matsumura, T., Uga, S., Nakagawa, M., Maehara ,T., Ono, K., Sumi, K. and Matsuoka, A. 1997. Seriepidemiological study of hantavirus infection in Nepal. J.A.R.M.A.M. 8: 81-86.

26. Schmaljohn, C. and Hjelle, B. 1997. Hantaviruses: a global disease problem. Emerg. Infect. Dis. 3: 95-104.

27. Song, J. W., Baek, L.J., Gajdusek, D. C., Yanagihara, R., Gavrilovskaya, I., Luft, B. J., Mackow, E. R. and Hjelle, B. 1994. Isolation of pathogenic hantavirus from white-footed mouse (peromyscus leucopus). Lancet 344: 8937.

28. Tsai, T. F. 1987. Hemorrhagic fever with renal syndrome: mode of transmission to humans. Lab Anim. Sci. 37: 428-430.

29. Yanagihara, R., Svedmyr, A., Amyx, H. L., Lee, P., Goldgaber, D., Gajdusek, D. C., Gibbs, C. J. Jr and Nystrom, K. 1984. Isolation and propagation of nephropathia epidemica virus in bank voles. Scand. J. Infect. Dis. 16: 225-228. 